P-ISSN 2442-6636

E-ISSN 2355-3987

www.ijhn.ub.ac.id

Artikel Hasil Penelitian

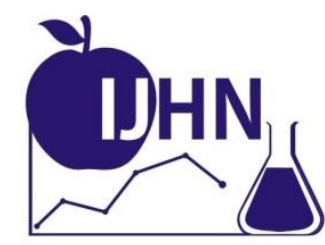

\title{
Asupan Zat Gizi Dan Kadar Hemoglobin Wanita Prakonsepsi Di Kabupaten Semarang
}

\author{
Annisa Khaira Maadi ${ }^{1}$, Fillah Fithra Dieny ${ }^{1 *}$, Hartanti Sandi Wijayanti ${ }^{1}$ A.Fahmy \\ Arif Tsani $^{1}$ Choirun Nissa ${ }^{1}$ \\ ${ }^{1}$ Program Studi Ilmu Gizi Departemen Ilmu Gizi, Fakultas Kedokteran, Universitas Diponegoro \\ *Alamat korespondensi: Email: fillahdieny@gmail.com, Tlp : +6285640204747
}

\begin{abstract}
Abstrak
Wanita prakonsepsi yang mengalami anemia berisiko mengalami berbagai masalah saat kehamilan. Salah satu faktor risiko anemia yaitu asupan zat gizi yang tidak adekuat. Penelitian ini bertujuan untuk menganalisis faktor asupan zat gizi yang berpengaruh terhadap kadar $\mathrm{Hb}$ wanita prakonsepsi. Penelitian ini menggunakan desain cross-sectional dengan 70 subjek pengantin wanita di KUA Kecamatan Sumowono dan Pringapus, berusia 16-35 tahun, dipilih dengan metode consecutive sampling. Data yang diambil yaitu berat badan, tinggi badan, asupan makan, dan kadar hemoglobin. Data asupan makan diperoleh menggunakan Semi Quantitative Food Frequency Questionnaire (SQ-FFQ). Data kadar $\mathrm{Hb}$ diukur menggunakan metode Cyanmethemoglobin. Analisis data menggunakan uji regresi linear sederhana dan regresi linear ganda. Hasil penelitian menunjukkan bahwa prevalensi anemia dan status gizi kurang sebanyak 11,4\% dan 15,7\%. Asupan energi, protein, vitamin $\mathbf{B}_{2}$, seng, besi dan asam folat tergolong kurang. Asupan energi $(p=0,004)$, protein $(p=0,007)$, zat besi $(p=0,009)$, dan status gizi $(p=0,055)$ merupakan faktor yang mempengaruhi kadar $\mathrm{Hb}$. Faktor yang paling berpengaruh terhadap kadar $\mathrm{Hb}$ adalah asupan energi dan status gizi. Kesimpulannya adalah kadar $\mathrm{Hb}$ pada wanita prakonsepsi dipengaruhi oleh asupan energi, protein, zat besi dan status gizi. Namun, faktor yang paling berpengaruh adalah asupan energi dan status gizi.
\end{abstract}

Kata kunci: asupan zat gizi, hemoglobin, wanita prakonsepsi

\begin{abstract}
Preconception women who have anemia are at risk of suffering problems during pregnancy. One of risk factors for anemia is inadequate nutrient intake. This study was aimed to analyze the factors of nutrient intakes that affect the level of $\mathrm{Hb}$ in preconception women. This study was conducted by using cross-sectional design study that consisted of 70 brides registered at Office of Religious Affairs in Sumowono and Pringapus Subdistricts, aged 16-35 years selected by consecutive sampling method. Weight, height, food intake, and hemoglobin level were measured. Food intake was obtained by using Semi Quantitative Food Frequency Questionnaire (SQ-FFQ). Hb level was measured by Cyanmethemoglobin method. Simple linear regression and multiple linear regression test were used to analyze the data. The result showed that the prevalence of anemia was 11,4\% and prevalence of undernutrition status was $15,7 \%$. Energy intake $(p=0,004)$, protein intake $(p=0,007)$, iron intake $(p=0,009)$, nutritional status $(p=0,055)$ were factors that affected $\mathrm{Hb}$ level. The most significant factors of $\mathrm{Hb}$ level were energy intake and nutritional status. The conclussion is $\mathrm{Hb}$
\end{abstract}


level in preconception women was affected by energy, protein, iron intake and nutritional status. However, the most significant factors with Hb level were energy intake and nutritional status.

Keywords: nutrients intake, hemoglobin, preconception women

\section{PENDAHULUAN}

Masa prakonsepsi merupakan masa penting bagi seorang wanita, karena erat kaitannya dengan kehamilan serta keadaan janin yang dikandungnya nanti. Kesehatan wanita pada masa prakonsepsi merupakan langkah untuk melindungi kesehatan ibu dan anak yang mungkin terjadi di masa depan. Hal ini sejalan dengan teori LCT ( Life Course Theory) yang berhipotesis bahwa output kelahiran dipengaruhi oleh interaksi jangka panjang dari biologis, perilaku, dan lingkungan (healthty food) dari wanita sebelum kehamilan. ${ }^{1}$

Masa prakonsepsi merupakan periode dalam siklus kehidupan yang tepat untuk mengetahui keadaan gizi ibu (sebelum periode kehamilan) dalam kaitannya dengan dampak kehamilan yang buruk dan mengurangi risiko terjadinya masalah gizi ibu selama kehamilan, salah satunya anemia. ${ }^{2,3}$ Prevalensi anemia pada ibu hamil di Indonesia masih tinggi, yaitu sekitar 37,1\%. ${ }^{4}$ Tingginya angka ini menjadi salah satu alasan penting dilakukannya pencegahan dini sejak masa prakonsepsi. Selain itu, WHO telah melaporkan sebanyak 58\% dari ibu hamil yang menderita anemia juga mengalami anemia sejak sebelum hamil. ${ }^{5}$ Oleh karena itu, akan memperparah kondisi anemia selama kehamilan, apalagi kondisi fisiologis ibu hamil yang rentan terjadinya anemia.

Upaya pencegahan maupun mengatasi anemia yang dilakukan pada masa prakonsepsi akan menimbulkan efek yang lebih baik dibandingkan jika dilakukan saat periode kehamilan. Wanita yang anemia berisiko mengalami keguguran karena dinding pembuluh darah mudah mengalami trombosis dari pembuluh darah uteroplasenta yang menyebabkan sirkulasi darah ke plasenta terganggu. Sebuah penelitan menyebutkan
$80 \%$ kasus keguguran terjadi pada awal kehamilan diusia kehamilan 12 minggu. $^{6}$ Oleh karena itu, efek keguguran ini dapat diatasi lebih dini jika diperhatikan semenjak masa prakonsepsi. Suplai zat gizi ke janin yang sedang tumbuh tergantung pada jumlah darah ibu yang mengalir ke plasenta dan zat-zat makanan yang diangkutnya. Ibu hamil yang anemia mengalami kekurangan pasokan oksigen dan masukan nutrisi, sehingga mengakibatkan gangguan pertumbuhan dan perkembangan janin. ${ }^{7}$ Sebuah studi juga menyebutkan kekurangan besi pada masa prakonsepsi telah terbukti meningkatkan risiko anemia defisiensi besi selama kehamilan dan bayi yang dilahirkan memiliki cadangan besi yang rendah, serta terkait dengan meningkatnya kelahiran prematur. Setengah dari perempuan Amerika Serikat memiliki simpanan besi yang tidak memadai ketika memasuki kehamilan. $^{8}$

Pengantin wanita merupakan kelompok wanita prakonsepsi yang rentan mengalami anemia. Wanita prakonsepsi rentan mengalami anemia dikarenakan asupan zat gizi yang kurang, mengalami menstruasi setiap bulannya, mayoritas menjadi pekerja dengan aktivitas fisik yang sedang hingga berat dan terbatasnya waktu untuk mengonsumsi makanan. ${ }^{9}$ Berdasarkan Riskesdas 2013, prevalensi anemia pada wanita usia subur (WUS) cukup tinggi sebesar 26,9\%. Angka ini lebih besar dari prevalensi anemia pada daur kehidupan remaja, yaitu $26,5 \% .^{4}$

Defisiensi asupan zat gizi makro, vitamin dan mineral berhubungan dengan kejadian anemia karena saling mempengaruhi dalam sintesis $\mathrm{Hb}$. Zat gizi makro yang berperan dalam sintesis $\mathrm{Hb}$ adalah energi dan protein. Tubuh membutuhkan energi untuk berlangsungnya proses fisiologis dan 
sintesis $\mathrm{Hb}$. Kekurangan energi menyebabkan kapasitas kerja tubuh terganggu dan terjadi pembongkaran cadangan protein. Protein berperan dalam transport besi, penyimpanan dan komponen hemoglobin, serta berperan dalam absorbsi besi. ${ }^{9,10,11}$ Vitamin seperti vitamin $A$, vitamin $C$, vitamin $B_{2}$, vitamin $\mathrm{B}_{6}$, vitamin $\mathrm{B}_{12}$ juga memiliki peran pada $\mathrm{Hb}$. Vitamin $\mathrm{C}$ membantu penyerapan besi di usus halus dengan mereduksi besi ferri menjadi ferro. ${ }^{12}$ Vitamin A berperan penting dalam proses eritropoiesis. Vitamin $\mathrm{B}_{6}$ yang berperan untuk sintesis heme adalah bentuk vitamin $\mathrm{B}_{6}$ aktif, yaitu pyridoxal phosphate (PLP) yang diaktifkan oleh vitamin $\mathrm{B}_{2}$. Vitamin $\mathrm{B}_{12}$ dapat mengubah asam folat menjadi bentuk aktifnya, dan asam folat diperlukan untuk pematangan eritrosit. ${ }^{13,14}$

Kecamatan Sumowono dan Pringapus merupakan daerah dengan prevalensi angka kematian bayi (AKB) dan angka kematian ibu (AKI) yang cukup tinggi dari tahun 2011-2016. AKI yang tercatat di Puskesmas Sumowono dan Pringapus masing-masing 5 kasus dalam waktu lima tahun. Sementara AKB di Kecamatan Pringapus dan Sumowono masing-masing 49 kasus dan 70 kasus. ${ }^{15}$ AKI dan AKB dapat dipengaruhi oleh status anemia. Keadaan ini didukung oleh penelitian tahun 2016 yang menunjukkan ibu hamil yang mengalami anemia memiliki peluang 9 kali lebih tinggi mengalami perdarahan post partum yang merupakan penyebab terbesar kematian ibu di negara berkembang. ${ }^{16}$ Oleh karena itu, peneliti ingin mengetahui faktor asupan zat gizi yang berpengaruh terhadap kadar hemoglobin pengantin wanita di Kecamatan Sumowono dan Kecamatan Pringapus, Kabupaten Semarang.

\section{METODE PENELITIAN \\ Rancangan/Desain Penelitian}

Penelitian ini termasuk dalam ruang lingkup keilmuan gizi masyarakat dengan rancangan cross-sectional study.

\section{Sumber Data}

Penelitian dilaksanakan pada bulan Januari 2018 hingga Mei 2018 berlokasi di Kantor Urusan Agama (KUA) Kecamatan Sumowono dan KUA Kecamatan Pringapus. Data penelitian antara lain pengukuran antoropometri, yaitu berat badan, tinggi badan, lingkar lengan atas (LLA), serta pengambilan darah dan pemeriksaan laboratorium untuk mengukur kadar hemoglobin.

\section{Sasaran Penelitian}

Populasi terjangkau dalam penelitian ini adalah pengantin wanita berusia 16-35 tahun yang terdaftar di KUA Kecamatan Sumowono dan Kecataman Pringapus pada bulan Januari 2018- Mei 2018. Subjek dalam penelitian adalah pengantin wanita, tidak merokok, tidak mengalami sakit kronis atau dalam perawatan dokter, tidak sedang menstruasi saat pengambilan darah serta bersedia mengisi formulir informed consent.

Besar sampel minimal dihitung berdasarkan rumus perhitungan sampel pada satu populasi, Nilai distribusi normal baku (tabelZ) pada $\alpha$ tertentu $Z=1,96$ pada $\alpha=0,05$ (dengan derajat kemaknaan 95\%), sedangkan deviat baku beta $(Z \beta 0,84)$. Jumlah sampel yang didapatkan adalah 70 pengantin wanita diambil dengan metode consecutive sampling.

\section{Pengembangan Instrumen dan Teknik Pengumpulan Data}

Data asupan zat gizi diperoleh dari 1 kali wawancara kepada subjek menggunakan Semi Quantitative-Food Frequency Questionnaire (SQ-FFQ) untuk asupan 1 bulan terakhir. Form SQ-FFQ terdiri dari 182 item bahan makanan yang telah disesuaikan dengan kebiasaan makan daerah setempat melalui survey 
pendahuluan awal dan ujicoba 1 bulan sebelum pengambilan data.

Data antropometri meliputi pengukuran berat badan menggunakan timbangan digital Camry dengan ketelitian $0.1 \mathrm{~kg}$ dan pengukuran tinggi badan menggunakan mikrotoise $G E A$ dengan ketelitian $0.1 \mathrm{~cm}$. Pengukuran berat dan tinggi badan dilakukan untuk mengetahui status gizi subjek dengan indikator Indeks Masa Tubuh (IMT) jika subjek berusia di atas 18 tahun, dan indikator z-score IMT menurut usia jika berusia $<18$ tahun. ${ }^{17}$

Pemeriksaan profil darah lengkap diperoleh dari pengambilan darah melalui vena sebanyak $3 \mathrm{cc}$ oleh tenaga analis kesehatan dari laboratorium Prodia Kota Semarang. Kadar $\mathrm{Hb}$ dianalisis dengan metode cyanmethemoglobin menggunakan alat Sysmex XT 2000i. Kadar $\mathrm{Hb}$ dinyatakan rendah jika $<12 \mathrm{~g} / \mathrm{dl} .{ }^{\mathbf{1 8}}$

\section{Teknik Analisis Data}

Data asupan yang diperoleh dalam ukuran rumah tangga dikonversikan kedalam satuan gram selanjutnya dianalisis dengan menggunakan software nutrisurvey 2007. Setelah dianalisis, asupan energi dan protein dibandingkan dengan kebutuhan masing-masing individu menggunakan rumus Harrist-Benedict menggunakan berat badan aktual, sedangkan asupan vitamin $A$, vitamin $C$, vitamin $B 2$, vitamin B6, vitamin B12, seng, zat besi dan folat dibandingkan dengan Angka Kecukupan Gizi (AKG) sesuai usia dan jenis kelamin. Asupan energi dan protein dikategorikan kurang jika $<80 \%$ AKG, cukup $80-100 \%$ AKG, dan lebih $>100 \%$ AKG. Asupan vitamin dan mineral dikategorikan menjadi 2 kategori, yaitu kurang $(<80 \%)$ dan baik $(>80 \%) \quad$ AKG. $^{19} \quad$ Analisis statistik menggunakan software statistik. Analisis univariat dilakukan untuk mendeskripsikan karakteristik subjek, kadar $\mathrm{Hb}$, dan asupan energi, protein, vitamin $\mathrm{A}$, vitamin $\mathrm{C}$, vitamin B2, vitamin B6, vitamin B12, seng, besi, folat dan status gizi. Analisis bivariat menggunakan uji regresi linear sederhana. Analisis multivariat menggunakan uji regresi linear ganda dengan metode backward. ${ }^{20}$

Penelitian ini telah mendapat nomor ethical clearance 58/EC/FK-RSDK/1/2018 yang disetujui oleh tim etik Penelitian Kesehatan Fakultas Kedokteran Undip-RS. Dr. Kariadi.

\section{HASIL PENELITIAN Karakteristik Subjek}

Data Karakteristik subjek penelitian terdiri dari usia, pendidikan dan status gizi ditampilkan pada tabel 1. Data nilai rerata, standar deviasi, median, nilai minimal dan maksimal kadar $\mathrm{Hb}$, asupan zat gizi, dan status gizi ditampilkan pada tabel 2 .

Berdasarkan tabel 1 diketahui sebanyak 28,5\% subjek masih berusia kurang dari 20 tahun. Sebanyak 88,6\% subjek sudah menjalani wajib belajar 9 tahun. Subjek yang bekerja sebesar $64,3 \%$, antara lain sebagai karyawan pabrik, wiraswasta, pedagang, petani, dan sisanya tidak bekerja. Sementara itu, status gizi subjek mayoritas $(70 \%)$ normal, namun masih ditemukan subjek yang memiliki status gizi kurang sebanyak $15,7 \%$ dan gizi lebih serta obesitas sebanyak 14,3\%.

Tabel 2 mendeskripsikan gambaran kategori variabel penelitian yaitu kadar $\mathrm{Hb}$, asupan energi, protein, vitamin $\mathrm{A}$, vitamin $C$, vitamin $B_{2}$, vitamin $B_{6}$, vitamin $B_{12}$, seng, zat besi, asam folat dan status gizi. Rerata kadar $\mathrm{Hb}$ subjek sebesar 13,2 g/dl termasuk dalam kategori normal. Namun terdapat kadar $\mathrm{Hb}$ subjek dengan nilai hanya 7,7 g/dl. Rerata asupan energi sebesar 1937,5 kkal dimana sudah memenuhi $80 \%$ kebutuhan. Median asupan protein sebesar 62,5 g sudah mencukupi kebutuhan harian subjek. 
Tabel 1. Karakteristik Subjek

\begin{tabular}{lrr}
\hline Karakteristik & $\mathrm{n}$ & $\%$ \\
\hline Usia & & \\
Remaja(16-20 tahun) & 20 & 28,5 \\
Dewasa (21-35 tahun) & 50 & 71,5 \\
Pendidikan & & \\
SD & 8 & 11,4 \\
SMP & 23 & 32,9 \\
SMA & 29 & 41,4 \\
D3/Sarjana & 10 & 14,3 \\
Pekerjaan & & \\
Bekerja & 45 & 64,3 \\
Tidak bekerja & 25 & 35,7 \\
Status Gizi & & \\
Gizi kurang & 11 & 15,7 \\
Normal & 49 & 70,0 \\
Gizi lebih & 3 & 4,3 \\
Obesitas & 7 & 10,0 \\
\hline
\end{tabular}

Asupan vitamin A memiliki rerata asupan yang melebihi AKG 2013 yaitu 2099 mcg, sedangkan kebutuhan vitamin A hanya $500-600 \mathrm{mcg}$. Nilai median vitamin C yaitu $112 \mathrm{mg}$. Angka ini melebihi kebutuhan AKG 2013 sebesar 75 mg, namun masih ada subjek dengan asupan vitamin $\mathrm{C}$ hanya 5,8 $\mathrm{mg}$. Nilai median asupan zat besi yaitu 9,5 $\mathrm{mg}$ dimana masih kurang dari kebutuhan zat besi, yaitu 26 mg. Rerata asupan seng sebesar 7,1 mg, hanya mencukupi $65 \%$ kebutuhan subjek. Asupan tertinggi asam folat mencapai 3999,9 mcg, namun jika dilihat rerata asupan asam folat masih dibawah $\mathrm{AKG}$ 2013, yaitu 246,3 mcg. Selain itu, rerata status gizi subjek berdasarkan IMT yaitu $21,5 \mathrm{~kg} / \mathrm{m}^{2}$, masih dalam kategori normal, akan tetapi masih terdapat subjek dengan nilai IMT terendah sebesar $15,6 \mathrm{~kg} / \mathrm{m}^{2}$ yang tergolong gizi kurang.

Tabel 2. Nilai Minimal, Maksimal, Rerata, Standar Deviasi, Median

\begin{tabular}{lrrrr}
\hline Variabel & Minimal & Maksimal & Rerata \pm SD & Median \\
\hline Kadar Hb (g/dl) & 7,7 & 16,0 & $13,2 \pm 1,2$ & 13,3 \\
Asupan Energi (kkal) & 802,8 & 3890,3 & $1937,5 \pm 733,3$ & 1795,5 \\
Asupan Protein (g) & 19,9 & 191,0 & $68,0 \pm 34,7$ & 62,5 \\
$\begin{array}{l}\text { Asupan Vitamin A } \\
\text { (mcg) }\end{array}$ & 198,5 & 13922,0 & $2099,0 \pm 1662,7$ & 1853,5 \\
Asupan Vitamin C (mg) & 5,8 & 1393,0 & $146,1 \pm 186,5$ & 112,0 \\
Asupan Vitamin B $(\mathrm{mg})$ & 0,2 & 3,8 & $0,9 \pm 0,5$ & 0,8 \\
$\begin{array}{l}\text { Asupan Vitamin B } \\
\text { (mg) }\end{array}$ & 0,3 & 3,7 & $1,3 \pm 0,7$ & 1,2 \\
$\begin{array}{l}\text { Asupan Vitamin B } \\
\text { (mg) }\end{array}$ & 0,2 & 58,6 & $4,4 \pm 7,4$ & 3,0 \\
$\begin{array}{l}\text { Asupan Seng (mg) } \\
\text { Asupan Besi (mg) }\end{array}$ & 2,2 & 17,3 & $7,1 \pm 3,4$ & 6,5 \\
$\begin{array}{l}\text { Asupan Asam Folat } \\
\text { (mcg) }\end{array}$ & 1,7 & 32,8 & $11,2 \pm 6,3$ & 9,5 \\
Status Gizi (kg/m $\left.{ }^{2}\right)$ & 31,5 & 3999,9 & $246,3 \pm 473,7$ & 170,4 \\
\hline
\end{tabular}


Gambaran dan Pengaruh Asupan Zat Gizi, Status Gizi Terhadap Kadar Hb

Tabel 3 menunjukkan 11,4\% subjek mengalami anemia. Subjek dengan asupan energi dan protein dalam kategori kurang, yaitu $37,1 \%$ dan $50 \%$. Asupan vitamin dan mikronutrien subjek masih kurang, yaitu vitamin $\mathrm{B}_{2}(72,9 \%)$, seng $(68,6 \%)$, zat besi $(92,9 \%)$, dan asam folat $(90 \%)$. Sebagian besar subjek $(68,6 \%)$, asupan vitamin $\mathrm{C}$ nya termasuk kategori baik. Asupan vitamin $A$, vitamin $B_{6}$ dan vitamin $B_{12}$ sebagian besar subjek $(97,1 \%, 64,3 \%$, $67,1 \%$ ) juga dalam kategori baik.

Tabel 4 menunjukkan bahwa asupan energi $(p=0,02)$, protein $(p=0,028)$, besi $(p=0,027)$, dan status gizi $(p=0,055)$ merupakan faktor berpengaruh dengan kadar hemoglobin pengantin wanita, namun, asupan vitamin $\mathrm{A}$, vitamin $\mathrm{C}$, vitamin $\mathrm{B}_{2}$, vitamin $\mathrm{B}_{6}$, vitamin $\mathrm{B}_{12}$, seng dan asam folat tidak berpengaruh terhadap kadar hemoglobin pengantin wanita $(p$ $>0,05$ ).

\section{Tabel 3. Distribusi Frekuensi Data Kadar Hb dan Asupan Zat Gizi}

\begin{tabular}{|c|c|c|}
\hline Variabel & $\mathrm{n}$ & $\%$ \\
\hline \multicolumn{3}{|l|}{ Kadar $\mathrm{Hb}$} \\
\hline Tidak anemia & 62 & 88,6 \\
\hline Anemia & 8 & 11,4 \\
\hline \multicolumn{3}{|l|}{ Asupan Energi } \\
\hline Kurang & 26 & 37,1 \\
\hline Cukup & 17 & 24,3 \\
\hline Lebih & 27 & 38,6 \\
\hline \multicolumn{3}{|l|}{ Asupan Protein } \\
\hline Kurang & 35 & 50,0 \\
\hline Cukup & 8 & 11,4 \\
\hline Lebih & 27 & 38,6 \\
\hline \multicolumn{3}{|l|}{ Asupan Vitamin A } \\
\hline Kurang & 2 & 2,9 \\
\hline Baik & 68 & 97,1 \\
\hline \multicolumn{3}{|l|}{ Asupan Vitamin C } \\
\hline Kurang & 22 & 31,4 \\
\hline Baik & 48 & 68,6 \\
\hline \multicolumn{3}{|l|}{ Asupan Vitamin $B_{2}$} \\
\hline Kurang & 51 & 72,9 \\
\hline Baik & 19 & 27,1 \\
\hline \multicolumn{3}{|c|}{ Asupan Vitamin $\mathrm{B}_{6}$} \\
\hline Kurang & 25 & 35,7 \\
\hline Baik & 45 & 64,3 \\
\hline \multicolumn{3}{|c|}{ Asupan Vitamin $B_{12}$} \\
\hline Kurang & 23 & 32,9 \\
\hline Baik & 47 & 67,1 \\
\hline \multicolumn{3}{|l|}{ Asupan Seng } \\
\hline Kurang & 48 & 68,6 \\
\hline Baik & 22 & 31,4 \\
\hline \multicolumn{3}{|l|}{ Asupan Besi } \\
\hline Kurang & 65 & 92,9 \\
\hline Baik & 5 & 7,1 \\
\hline \multicolumn{3}{|c|}{ Asupan Asam Folat } \\
\hline Kurang & 63 & 90,0 \\
\hline Baik & 7 & 10,0 \\
\hline
\end{tabular}


Tabel 4. Pengaruh Asupan dan Status Gizi dengan Kadar Hb

\begin{tabular}{|c|c|c|}
\hline Variabel & B & $\mathrm{p}$ \\
\hline Asupan Energi (kkal) & 0,011 & $0,004^{*}$ \\
\hline Asupan Protein (g) & 0,009 & $0,007^{*}$ \\
\hline Asupan Vitamin A (mcg) & 0,001 & 0,165 \\
\hline Asupan Vitamin C (g) & 0,001 & 0,346 \\
\hline Asupan Vitamin $\mathrm{B}_{2}(\mathrm{mg})$ & 0,003 & 0,465 \\
\hline Asupan Vitamin $\mathrm{B}_{6}(\mathrm{mg})$ & $-0,002$ & 0,413 \\
\hline Asupan Vitamin $B_{12}(\mathrm{mg})$ & 0,001 & 0,139 \\
\hline Asupan Seng (mg) & 0,001 & 0,819 \\
\hline Asupan Besi (mg) & 0,016 & $0,009^{*}$ \\
\hline Asupan Folat (mcg) & 0,002 & 0,083 \\
\hline Status Gizi (kg/m²) & 0,089 & $0,055^{*}$ \\
\hline
\end{tabular}

*signifikan $(p<0,05)$

Faktor yang Paling Berpengaruh terhadap Kadar $\mathrm{Hb}$

Tabel 5 menunjukkan hasil analisis multivariat menggunakan regresi linear berganda. Variabel yang memenuhi syarat untuk dilakukan uji regresi linear berganda adalah variabel yang pada analisis bivariat mempunyai nilai $\mathrm{p}<0,25$, yaitu asupan energi, protein, vitamin $\mathrm{A}$, vitamin $\mathrm{B}_{12}$, zat besi, asam folat dan status gizi.

Hasil analisis multivariat pada tabel 5 mendeskripsikan bahwa asupan energi dan status gizi merupakan variabel yang paling berpengaruh terhadap kadar $\mathrm{Hb}$ dengan nilai $\mathrm{p}$ masing-masing, yaitu 0,044 dan 0,030. Kadar $\mathrm{Hb}$ dapat dijelaskan oleh asupan energi dan status gizi sebesar $17 \%$, sedangkan sisanya dipengaruhi oleh variabel lain yang tidak diteliti. Koefisien regresi menyatakan bahwa setiap peningkatan 1 kkal energi/hari akan meningkatkan kadar $\mathrm{Hb}$ sebesar 0,008 g/dl, dan setiap peningkatan $1 \mathrm{~kg} / \mathrm{m}^{2}$ status gizi akan meningkatkan kadar $\mathrm{Hb}$ sebesar $0,095 \mathrm{~g} / \mathrm{dl}$. Sementara itu, dapat dibuat persamaan regresi sebagai berikut : Kadar $\mathrm{Hb}=9,902+0,008$ (Asupan Energi) + 0,095 (Status Gizi).

Tabel 5. Faktor yang Paling Berpengaruh

\begin{tabular}{lccc}
\hline Variabel & $\mathrm{B}$ & $p$ & Adjusted R $^{2}$ \\
\hline Energi & 0,008 & $0,044^{\mathrm{a}}$ & 0,170 \\
Status Gizi & 0,095 & $0,030^{\mathrm{a}}$ & \\
Konstanta & 9,902 & & \\
\hline
\end{tabular}

${ }^{a}$ Uji Regresi Linear Ganda

\section{PEMBAHASAN}

\section{Karakteristik Subjek}

Prevalensi anemia pada pengantin wanita ditemukan sebesar $11,4 \%$ dan prevalensi gizi kurang sebesar $15,7 \%$. Angka gizi kurang ini sedikit lebih tinggi dibandingkan prevalensi nasional wanita kurus di Indonesia sebesar $10,9 \%{ }^{4}$ Status gizi kurang subjek dapat disebabkan oleh faktor asupan makan yang kurang dari kebutuhan dalam waktu lama dan asupan makan yang kurang beragam. Selain itu, mayoritas subjek yang mengalami gizi kurang adalah pekerja pabrik yang menyebabkan frekuensi makan dalam sehari yang masih rendah karena shift kerja yang terlalu pagi dan jarak antara tempat tinggal dengan lokasi kerja cukup jauh, 
sehingga memungkinkan subjek berangkat lebih awal dan melewatkan sarapan. Selain itu, penelitian tahun 2015 di Tegal menyebutkan pekerja wanita yang mengalami underweight cukup tinggi yaitu $37,5 \%$. Underweight dipengaruhi oleh faktor beban kerja yang berlebih sehingga berisiko terjadinya penurunan berat badan. ${ }^{21}$ Faktor penyebab gizi kurang tersebut juga dapat menyebabkan anemia, meskipun prevalensi anemia di penelitian ini masih termasuk masalah kesehatan masyarakat dengan kategori ringan menurut WHO. ${ }^{19}$ Status gizi kurang pada subjek merupakan keadaan yang sudah berlangsung lama (kronis). Hal ini perlu mendapat perhatian, karena status gizi yang baik pada wanita prakonsepsi dapat meminimalkan risiko masalah kesehatan bagi ibu dan bayi selama kehamilan. ${ }^{22}$

Asupan energi, protein, vitamin $\mathrm{B}_{2}$, seng, zat besi dan asam folat subjek penelitian sebagian besar tergolong kurang. Salah satu penyebab asupan zat gizi kurang karena sebagian besar subjek adalah pekerja. Mereka sering melewatkan makan atau makan lebih sedikit karena waktu mengonsumsi makanan yang singkat. Selain kekurangan waktu, makanan yang dikonsumsi subjek juga kurang beragam. Subjek lebih sering mengonsumsi sumber bahan makanan nabati seperti sayuran, kacang-kacangan dan buah-buahan. Dibandingkan sumber makanan hewani, Sumber makanan hewani yang biasa mereka konsumsi adalah ikan, telur ayam dan daging ayam, meskipun frekuensi konsumsi makanan tersebut tidak setiap hari. Konsumsi makanan hewani yang kurang beragam dan jumlah yang sedikit dapat menyebabkan kekurangan asupan protein, zat besi, seng dan asam folat. Seperti yang diketahui, bahan pangan sumber hewani mengandung tingkat protein yang relatif tinggi (lebih dari $40 \%$ dari bahan kering) dibandingkan dengan pangan nabati yang memiliki kadar protein kurang dari 15 persen (basis bahan kering). ${ }^{23}$ Sumber terbaik zat besi dan seng dari makanan berasal dari sumber hewani yaitu daging merah dan hati, lalu diikuti oleh makanan laut. Kandungan zat besi dari pangan hewani seperti daging dan hati sapi lebih tinggi dibandingkan bahan pangan nabati. ${ }^{11}$ Kebiasaan subjek yang jarang mengonsumsi susu dan produk susu menyebabkan asupan vitamin $\mathrm{B}_{2}$ kurang. Mereka lebih sering mengonsumsi teh atau kopi. Sumber asam folat yang sering dikonsumsi subjek adalah sayuran hijau dan kacang-kacangan. Meskipun sering mengonsumsi sayuran hijau dan kacangkacangan, namun porsi yang dikonsumsi tidak cukup untuk memenuhi AKG yaitu $400 \mathrm{mcg}$.

Asupan vitamin $\mathrm{A}$, vitamin $\mathrm{C}$, vitamin $\mathrm{B}_{6}$, dan vitamin $\mathrm{B}_{12}$ sebagian besar subjek sudah mencukupi kebutuhan. Kebiasaan subjek yang sering mengonsumsi sayuran berwarna orange, sayuran berdaun, dan minyak kelapa sawit merupakan salah satu alasan terpenuhinya asupan vitamin A subjek. Pemenuhan asupan vitamin A terutama sumber nabati mudah ditemukan dan harganya relatif murah, serta banyaknya terdapat produkproduk sumber fortifikasi vitamin A. ${ }^{24}$ Subjek sering mengonsumsi buah-buahan baik dalam bentuk buah utuh ataupun jus buah dikarenakan akses yang mudah untuk memperoleh makanan tersebut dari tempat tinggal mereka, sehingga asupan vitamin $\mathrm{C}$ subjek tergolong cukup. Asupan vitamin $\mathrm{B}_{6}$ subjek terpenuhi dari kebiasaan subjek yang mengonsumsi nasi putih, pisang, dan telur ayam. Penelitian di Brazil tahun 2016 menyebutkan nasi putih berkontribusi sebesar 9,93\% pada pemenuhan asupan vitamin $\mathrm{B}_{6}{ }^{25}$ Pemenuhan sumber vitamin $\mathrm{B}_{12}$ subjek diperoleh dari tahu, tempe dan telur ayam, yang merupakan salah satu sumber dari vitamin $\mathrm{B}_{12}$.

\section{Asupan Zat Gizi Dan Status Gizi Dengan Kadar $\mathrm{Hb}$}

Hasil analisis menunjukkan asupan energi berpengaruh signifikan dengan kadar $\mathrm{Hb}$. Hasil ini sejalan dengan penelitian di 
Purbalingga yang menyatakan semakin rendah asupan energi semakin rendah pula kadar hemoglobin. ${ }^{9}$ Asupan energi inadekuat akan berdampak pada ketersediaan zat gizi makro lain di dalam tubuh. Tubuh membutuhkan energi untuk berlangsungnya proses fisiologis dan membantu kerja tubuh dalam metabolisme zat gizi yang berperan dalam pembentukan $\mathrm{Hb}$. Dalam keadaan rendahnya ketersediaan energi pada wanita prakonsepsi, mengganggu aktivitas enzim glikolitik seperti heksokinase, kinase piruvat dan glukosa 6-fosfat dehidrogenase (G6PD) dapat mengubah permeabilitas membran, yang mengarah pada pemecahan sel darah merah. Temuan ini menjelaskan bahwa wanita prakonsepsi yang kekurangan energi cenderung mengalami defisiensi zat besi, yang terlihat dari kadar $\mathrm{Hb}$ rendah. $^{22}$ Hasil ini didukung oleh penelitian ditahun 2016 pada wanita pranikah yang membuktikan hubungan yang signifikan antara asupan energi yang kurang dengan deplesi besi dan Iron Deficiency Erythropoesis (IDE). ${ }^{22}$

Asupan protein berpengaruh signifikan terhadap kadar $\mathrm{Hb}$. Asupan protein pada masa prakonsepsi yang inadekuat dapat mengakibatkan gangguan metabolisme zat besi karena protein merupakan transporter zat besi ke sum sum tulang untuk pembentukan $\mathrm{Hb}$, sehingga berisiko terjadinya anemia sebelum kehamilan maupun selama kehamilan. ${ }^{19,26}$ Selain berperan dalam transport besi, asam amino glisin berperan sebagai bahan awal sintesis heme. ${ }^{27}$ Hal ini sejalan dengan penelitian kohort pada wanita yang dilakukan di Amerika Serikat membuktikan bahwa semakin rendah asupan protein, semakin rendah pula kadar $\mathrm{Hb}^{28}$

Asupan zat besi memiliki pengaruh signifikan terhadap kadar Hb. Keterkaitan zat besi dengan kadar $\mathrm{Hb}$ dapat dijelaskan bahwa zat besi merupakan komponen utama yang berperan dalam proses sintesis $\mathrm{Hb}^{29}$ Zat besi dari makanan akan diserap dalam bentuk $\mathrm{Fe}^{2+}$ di duodenum melalui Haem Carier Protein (HCP1) lalu masuk ke enterosit oleh transporter Divalent Metal Tranproter (DMT1). Kemudian, zat besi diangkut oleh ferroportin ke aliran darah dan bergabung dengan protoporphyrin membentuk heme yang berikatan dengan globin untuk sintesisi Hb. ${ }^{30,31}$ Asupan zat besi yang rendah selama masa prakonsepsi mempengaruhi kadar $\mathrm{Hb}$ dan feritin sehingga dapat berisiko pada pertumbuhan janin yang buruk dan kejadian BBLR 6,5 kali lebih tinggi dibandingkan wanita dengan asupan zat besi yang cukup. ${ }^{32}$

Asupan vitamin $\mathrm{C}$ dan kadar $\mathrm{Hb}$ dalam penelitian ini tidak menunjukkan pengaruh yang signifikan. Hal ini mungkin disebabkan karena asupan vitamin $\mathrm{C}$ yang sebagian besar bersumber dari buahbuahan dengan kandungan serat yang tinggi dapat mengganggu penyerapan zat besi non-heme. ${ }^{33}$ Pada penelitian ini, sumber vitamin $\mathrm{C}$ yang banyak dikonsumsi subjek berasal dari buah-buahan tinggi serat seperti pisang, alpukat, dan pepaya, selain itu subjek mengonsumsi buahbuahan tidak bersamaan dengan sumber zat besi. Mereka lebih sering mengonsumsi buah sebagai makanan selingan baik dalam bentuk buah segar maupun jus buah. Selain itu, kebiasaan makan sumber vitamin $\mathrm{C}$ yang tidak bersamaan dengan makanan sumber zat besi sehingga tidak memiliki dampak signifikan terhadap fungsi vitamin $\mathrm{C}$ dalam membantu penyerapan zat besi. ${ }^{33}$ Hasil ini sejalan dengan penelitian pada wanita usia 19-25 tahun yang menyebutkan tidak ada hubungan asupan vitamin $\mathrm{C}$ dengan kadar $\mathrm{Hb}^{34}$

Vitamin A dan kadar $\mathrm{Hb}$ tidak memiliki pengaruh yang signifikan dalam penelitian ini. Secara teori, vitamin A berperan memobilisasi cadangan besi di hati untuk sintesis $\mathrm{Hb}$, meningkatkan eritropoesis, mengurangi anemia yang disertai infeksi, dan memiliki efek pada beberapa hormon dan sitokin yang terlibat dalam regulasi Fe. ${ }^{35}$ Penelitian mengenai asupan vitamin $\mathrm{A}$ dengan kadar $\mathrm{Hb}$ masih 
memiliki hasil yang berbeda-beda. Salah satu penelitian menyebutkan tidak adanya hubungan asupan vitamin $\mathrm{A}$ dan kadar $\mathrm{Hb}$ dipengaruhi oleh kecukupan asupan lemak. $^{36}$ Vitamin A merupakan vitamin larut lemak, sehingga meskipun asupan vitamin A cukup, absorbsinya tidak akan maksimal ketika asupan lemak kurang. ${ }^{37}$ Dalam penelitian ini, asupan lemak tidak dianalisis sehingga tidak diketahui kecukupan asupan lemak subjek.

Asupan asam folat tidak berpengaruh signifikan dengan kadar $\mathrm{Hb}$. Tidak adanya pengaruh pada penelitian ini kemungkinan karena asam folat mudah hancur saat proses pemasakan dan kualitasnya menurun selama proses penyimpanan. ${ }^{38}$ Asam folat dibutuhkan dalam pembentukan sel darah merah. Selain itu, asam folat juga berperan sebagai pembawa karbon tunggal dalam pembentukan heme. ${ }^{39}$ Asupan asam folat yang kurang pada wanita akan menyebabkan gangguan pematangan inti eritrosit, yang berakibat timbulnya sel darah dengan ukuran dan bentuk yang tidak normal. Bentuk hematopoesis yang tidak normal ini dapat menyebabkan anemia. ${ }^{23,40}$

Asupan seng tidak berpengaruh signifikan dengan kadar $\mathrm{Hb}$. Hal ini dikarenakan sebagian besar asupan protein kurang dari kebutuhan, dimana protein berperan sebagai transporter yang mengangkut seng dan sebagai ligan untuk meningkatkan penyerapan. Beberap hasil penelitian menunjukkan bahwa penyerapan seng akan meningkat secara linear dengan meningkatnya jumlah protein. Selain itu, kebiasaan subjek yang sering mengonsumsi makanan nabati banyak mengandung fitat yang menurunkan bioavaibilitas seng. ${ }^{41}$ Hasil ini sejalan dengan penelitian tahun 2015 yang dilakukan di Semarang pada wanita usia 23-25 tahun bahwa tidak ada korelasi asupan seng dengan kadar $\mathrm{Hb}^{42}$ Peran seng dalam tubuh sebagai bahan sintesis Hb. Seng dari makanan berinteraksi dengan zat besi secara langsung yaitu sebagai kofaktor enzim
Amino levulinic heme (ALA)-dehidratase yang berperan dalam sintesis heme saat berada pada sitosol sel sumsum tulang. ${ }^{43}$ Selain itu, di lambung seng membantu enzim karbonik anhidrase esensial untuk merangsang produksi HCL lambung sehingga zat besi lebih mudah diserap mukosa usus. ${ }^{44}$ Efek negatif interaksi seng dengan zat besi hanya ditemukan dalam bentuk sumplementasi dengan media larutan, bukan dari makanan. ${ }^{45}$

Status vitamin B merupakan hal penting yang perlu diperhatikan pada wanita prakonsepsi untuk mengurangi risiko komplikasi kehamilan dini, seperti aborsi spontan dan masalah status gizi. ${ }^{46}$ Pada penelitian ini, asupan vitamin $B_{2}$, Vitamin $\mathrm{B}_{6}$, dan vitamin $\mathrm{B}_{12}$ tidak berpengaruh signifikan dengan kadar $\mathrm{Hb}$. Tidak adanya pengaruh signifikan ini dapat disebabkan ada faktor lain yang mempengaruhi bioavaibilitas vitamin $\mathrm{B}$ kompleks pada saat pengolahan bahan pangan yang tidak dikaji dalam penelitian ini. $^{45}$ Vitamin $\mathrm{B}_{2}$ dan metabolitnya yang disimpan dalam bentuk Flavin Adenin Difosfat (FAD) mewakili 70-90\% vitamin tersebut. Oleh karena itu, meskipun sebagian asupan vitamin $\mathrm{B}_{2}$ subjek kurang dari kebutuhan, tubuh tetap dapat memenuhi dari simpanan tersebut sehingga dapat masih dapat mendukung sintesis $\mathrm{Hb}$, dan tidak mempengaruhi kadar $\mathrm{Hb}^{47}$ Kekurangan vitamin $\mathrm{B}_{2}$ dan zat besi sering terjadi bersamaan ketika sumber asupan hewani rendah. Defisiensi vitamin $\mathrm{B}_{2}$ dapat mengganggu penyerapan dan mobilisasi zat besi intraselular sehingga sangat memungkinkan mengganggu sintesis globin, sehingga zat besi di ferritin tertahan dan tidak tersedia untuk eritropoesis. ${ }^{33}$

Analisis statistik menunjukkan terdapat pengaruh yang signifikan antara status gizi dengan kadar $\mathrm{Hb}$ pengantin wanita. Pada penelitian ini korelasi yang dihasilkan bernilai positif artinya semakin rendah status gizi maka kadar $\mathrm{Hb}$ juga semakin rendah. Korelasi positif yang dihasilkan karena status gizi subjek 
sebagian besar tergolong normal. Wanita dengan status gizi kurang dapat meningkatkan risiko anemia karena berisiko kekurangan mikronutrien, termasuk kekurangan zat besi sehingga dapat terjadi deplesi besi dan IDE. $^{48}$ Underweight karena kekurangan energi protein dapat menghambat maturasi eritrosit, menurunkan jumlah sel erytropoetin-sensitive precursor dan memungkinkan kekurangan eritropoetin sehingga berisiko terjadinya anemia. ${ }^{48} \mathrm{Di}$ sisi lain, status status gizi lebih juga dapat menyebabkan anemia. ${ }^{49}$ Status gizi yang lebih pada wanita akan menyebabkan peningkatan sitokin pro-inflamasi, khususnya IL-6 yang tinggi dalam darah yang akan merangsang produksi hepsidin. Produksi hepsidin yang tinggi dapat menghambat penyerapan zat besi. ${ }^{31,50,51}$

Berdasarkan uji regresi linear ganda, faktor yang paling mempengaruhi kadar $\mathrm{Hb}$ adalah asupan energi $(p=0,044)$ dan status gizi $(p=0,030)$. Asupan energi dari makanan merupakan faktor yang berpengaruh langsung secara linear dalam menentukan status gizi. Status gizi merupakan keadaan keseimbangan antara pemasukan dan pengeluaran energi tubuh. ${ }^{42}$ Ketika asupan energi tubuh kurang, maka dapat menurunkan nilai IMT. ${ }^{52}$ Kekurangan asupan energi dapat mengganggu aktivitas enzim glikolitik seperti hexokinase, kinase piruvat dan glukosa 6-fosfat dehidrogenase (G6PD) yang mengubah permeabilitas membran, yang mengarah pada pemecahan sel darah merah. Hal ini menjelaskan perempuan yang memiliki status gizi kurang cenderung kekurangan zat besi yang terlihat dari nilai $\mathrm{Hb}$ yang rendah. ${ }^{22}$ Kekurangan asupan energi berisiko 3,2 kali lebih besar mengalami kekurangan gizi (IMT $<18,5$ $\mathrm{kg} / \mathrm{m}^{2}$ ) dibandingkan dengan WUS yang memiliki asupan energi cukup. ${ }^{53}$ Penelitian lain menyebutkan bahwa wanita underweight berisiko 6 kali lebih tinggi mengalami kekurangan simpanan besi dan
4 kali lebih tinggi mengalami IDE dibandingkan dengan wanita normal. ${ }^{22}$

Calon pengantin wanita dekat hubungannya dengan kehamilan dan menyusui, oleh karena itu perbaikan status gizi dan anemia gizi besi serta defisiensi folat harus dilakukan pada periode ini untuk memperoleh kualitas generasi penerus yang baik. ${ }^{54}$

\section{SIMPULAN}

Kadar $\mathrm{Hb}$ wanita prakonsepsi dipengaruhi oleh asupan energi, protein, zat besi, dan status gizi. Faktor yang paling berpengaruh terhadap kadar $\mathrm{Hb}$ adalah asupan energi dan status gizi.

\section{UCAPAN TERIMAKASIH}

Terima kasih kepada subjek penelitian, KUA Kecamatan Pringapus dan Kecamatan Sumowono, serta Departemen Ilmu Gizi FK Undip. Penelitian ini dibiayai oleh hibah RPP Fakultas Kedokteran Universitas Diponengoro.

\section{DAFTAR RUJUKAN}

1. Denny A, Stanner S. Preconception Health:The Role of Nutrition. Clincal Focus Nutr. 2008:52-4.

2. Greaves L, Poole N. Preconception care Call for national guidelines. Canadian Family Physician. 2013;59(1):1037-39.

3. Van Driel LMJW, Zwolle LJH, de Vries JHM, Boxmeer JC, Lindemans J, Steegers EAP, et al. The preconception nutritional status of women undergoing fertility treatment: Use of a one-year post-delivery assessment. e-SPEN. 2010;5(6):284-91.

4. Badan Penelitian dan Pengembangan Kesehatan. Riset Kesehatan Dasar (RISKESDAS) 2013. 2013;1-384.

5. Ma Q, Zhang S, Liu J, Wang Q, Shen H, Zhang Y, et al. Study on the prevalence of severe anemia among non-pregnant women of reproductive age in rural China: A large population-based crosssectional study. Nutrients. 2017;9(12):115. 
6. Handayani TR. Determinan Kejadian Anemia Defisiensi Zat Besi Pada ibu Hamil Di Puskesmas Nagaswidak Palembang Tahun 2017. 2017;5(2):345356.

7. Suhartati S, Rahmawaty L, Mulia SS, Mulia AS. Hubungan Anemia pada Ibu Hamil dengan Kejadian BBLR Di Wilayah Kerja Puskesmas Tanta Kabupaten Tabalong Tahun 2016. Dinamika Kesehatan. 2017;8(1):45-54.

8. Brown JE. Nutrition through the Life Cycle. Fourth Edition. Fluoride. USA: Wadsworth; 2011. 51-70.

9. Mantika, A.I., Mulyati T. Hubungan Asupan Energi, Protein, Zat Besi Dan Aktivitas Fisik Dengan Kadar Hemoglobin Tenaga Kerja Wanita Di Pabrik Pengolahan Rambut Pt. Won Jin Indonesia. Journal of Nutrition Collage. 2014;3(4):848-854.

10. Wieringa F, Marjoleine D. Nutritional Anemia in Developing Countries. Nutripass. 2010. 151-170.

11. Kathleen L, Escott-Stum S. Krause's, Food and Nutrition Therapy. Saunders Elsevier. Canada: Elsevier Ltd; 2008. 114-120 p.

12. Safwan A, Asar F. Association between Hemoglobin status with Vitamin C Intake. Adv Obes Weight Manag Control. 2017;6(1):1-4.

13. Paul L, Selhub J. Interaction between excess folate and low vitamin B12 status. Molecular Aspects of Medicine. 2017;53:43-7.

14. Balarajan $Y$, Ozaltin E, Shankar A, Subramanian S. Anaemia in low-income and middle-income countries. Lancet . 2011;37:2123-35.

15. Dinas Kesehatan Kabupaten Semarang. Profil Kesehatan Kabupaten Semarang. 2016. 12-17

16. Jayanti KD, N HB, Wibowo A. Faktor Yang Mempengaruhi Kematian Ibu (Studi Kasus Di Kota Surabaya). Jurnal Wiyata. 2016;3(1):46-53.

17. Hardinsyah, Supariasa IDN. Ilmu Gizi Teori dan Aplikasi. Jakarta: Penerbit
Buku Kedokteran EGC; 2016. 131.

18. McLean E, Cogswell M, Egli I, Wojdyla $\mathrm{D}$, de Benoist B. Worldwide prevalence of anaemia, WHO Vitamin and Mineral Nutrition Information System, 19932005. Public Health Nutrition. 2009;12(4):444-54.

19. Kusharto CM, Supariasa IDN. Survey Konsumsi Gizi. Yogyakarta: Graha Ilmu; 2014. 59.

20. Sugiyono. Statistik untuk Penelitian. 7th edition. Nuryanto A, editor. Bandung: ALFABETA; 2005. 243-254 p.

21. Widiastuti S, Dieny FF. Faktor determinan produktivitas kerja pada pekerja wanita. Jurnal Gizi Indonesia. 2016;4(1):28-37.

22. Sumarmi S, Puspitasari N, Handajani R, Wirjatmadi B. Underweight as a risk factor for iron depletion and irondeficient erythropoiesis among young women in rural areas of East Java, Indonesia. Mal J Nutr 2016;22(2):219-232.

23. Wu G, Fanzo J, Miller DD, Pingali $P$, Post M, Steiner JL, et al. Production and supply of high-quality food protein for human consumption: Sustainability, challenges, and innovations. Ann. N. Y. Acad. Sci. 2014;1321(1):1-19.

24. Wallace LJ, Summerlee AJS, Dewey CE, Hak C, Ann Hall NP, Charles C V. Women's nutrient intakes and foodrelated knowledge in rural Kandal province, Cambodia. Asia Pac J Clin Nutr. 2014;23(2):263-271.

25. Steluti J, Martini LA, Peters BSE, Marchioni DML. Folate, vitamin B6 and vitamin B12 in adolescence: serum concentrations, prevalence of inadequate intakes and sources in food. $\mathrm{J}$ Pediatr (Rio J). 2011;87(1):43-9.

26. Murray R, Graner D, Rodwell V. Biokimia Harper. 27th Edition. Jakarta: EGC; 2009. 44-51.

27. Ayu D. Pengaruh suplementasi glisin terhadap kadar serum transferrin receptor (STFR) dan kadar hemoglobin $(\mathrm{Hb})$. Jurnal Gizi Indonesia. 
2015;4(1):22-27.

28. Thomson CA, Stanaway JD, Neuhouser ML, Snetselaar LG, Stefanick ML, Arendell L, et al. Nutrient Intake and Anemia Risk in the Women's Health Initiative Observational Study. J Am Diet Assoc. 2011;111(4):532-541.

29. Hardinsyah, Supariasa ID nyoman. Ilmu Gizi, Teori \& Aplikasi. Jakarta: EGC, Penerbit Buku Kedokteran; 2016. 87-88.

30. Percy L, Mansour D, Fraser I. Iron deficiency and iron deficiency anaemia in women. Best Practice \& Research Clinical Obstetrics and Gynaecology. 2017;40:55-67.

31. Perdana WY, Jacobus DJ. Hepcidin dan Anemia Defisiensi Besi. Cdk-235. 2015;42(12):919-926.

32. Gardiner PM, Nelson L, Shellhaas CS, Dunlop AL, Long R, Andrist S, et al. The clinical content of preconception care: nutrition and dietary supplements. American Journal of Obstetrics \& Gynecology. 2008;199(6):345-356.

33. Asthalina H, Laraeni $Y$, Putri $Y$, Jurusan D, Poltekkes G, Mataram K, et al. Pola Konsumsi (Faktor Inhibitor Dan Enhancer Fe) Terhadap Status Anemia Remaja Putri. Kemas. 2015;11(1):8086.

34. Safwan A, Ahsan F. Association between Hemoglobin status with Vitamin C Intake. Ads Obes Weight Manag Control. 2017;6(1). 1-4.

35. Michelazzo FB, Oliveira JM, Stefanello J, Luzia LA, Rondó PHC. The influence of vitamin A supplementation on iron status. Nutrients. 2013;5(11):43994413.

36. Sahana ON, Sumarmi S. Hubungan Asupan Mikronutrien Dengan Kadar Hemoglobin Pada Wanita Usia Subur (WUS). Media Gizi Indonesia. 2014;10(2):184-191.

37. S.Gibson R. Principle of Nutritional Assessment. 2th Editio. New York: Oxford University Press.Inc; $2005.446 \mathrm{p}$

38. Scoot J. Nutritional anemia: B-vitamins. Germany: Sight And Life Press; 2007.
111.

39. Cendani C, Murbawani EA. Asupan Mikronutrien, Kadar Hemoglobin dan Kesegaran Jasmani Remaja Putri. Media Medika Indonesia. 2011;45(1):25-33.

40. Metz Jack. A High Prevalence of Biochemical Evidence of Vitamin B12 or Folate Deficiency Does Not Translate Into a Comparable Prevalence of Anemia. Food and Nutrition Bulletin. 2008;29(2):75-85.

41. Bel-Serrat S, Stammers AL, WarthonMedina M, Moran VH, Iglesia-Altaba I, Hermoso M, et al. Factors that affect zinc bioavailability and losses in adult and elderly populations. Nutrition Reviews. 2014;72(5):334-352.

42. Triyonate EM, Kartini A. Faktor Determinan Anemia Pada Wanita Dewasa Usia 23-35 Tahun. J Nutr Coll. 2015;4(3):259-63.

43. Murray R, W.Rodwell V. Biokimia Harper. 27th Ed. Jakarta: Penerbit Buku Kedokteran; 2009.

44. Dewi RC. Pengaruh Suplementasi Tablet Tambah Darah (TTD), Seng, dan Vitamin A Terhadap Kadar Hemoglobin Ibu Hamil. MKM. 2008;03(01):12-19.

45. S.Gropper S, L.Groff J. Advanced Nutrition and Human Metabolism. 5 ed. USA: Wadsworth Cengage Learning; 2009. 429-469.

46. A.G. Ronnerberg, M.B. Goldman, D. Chen, I.W. Aitken, W.C. Willett, J. Shellhub. Preconception folate and vitamin B6 status and clinical spontaneous abortion in Chinese women. The American College of Obstetricians and Gynecologist. 2002;100(1):107-113.

47. S.Gibson R. Principles of Nutritional Assessment. 2nd Edition. New York: Oxford University Press.Inc; 2005. 479.

48. Warner RP, Dole MG, Warder J, Suskind RM. The Anemia of Malnutrition. The Malnourished Child. 1990;19(5):61-72.

49. Qin Y, Melse-Boonstra A, Pan X, Yuan B, Dai $Y$, Zhao J, et al. Anemia in 
relation to body mass index and waist circumference among chinese women. Nutrition Journal. 2013;12(10):1-3.

50. Cepeda-Lopez AC, Osendarp SJM, Melse-Boonstra A, Aeberli I, GonzalezSalazar F, Feskens E, et al. Sharply higher rates of iron deficiency in obese Mexican women and children are predicted by obesity-related inflammation rather than by differences in dietary iron intake. Am J Clin Nutr. 2011;93(5):975-983.

51. Stankowiak-Kulpa $H$, Kargulewicz A, Styszynski A, Swora-Cwynar E, Grzymislawski M. Iron status in obese women. Annals of Agricultural and Environmental Medicine. 2017;24(4):587-591.
52. Cheng HL, Bryant CE, Rooney KB, Steinbeck KS, Griffin HJ, Petocz P, et al. Iron, Hepcidin and Inflammatory Status of Young Healthy Overweight and Obese Women in Australia. Plos One. 2013;8(7):1-6.

53. Paratmanitya $\mathrm{Y}$, Hadi H. Citra tubuh , asupan makan, dan status gizi wanita usia subur pranikah. Jurnal Gizi Klinik Indonesia. 2012;8(3):126-134.

54. Dieny FF, Rahadiyanti A, Kurniawati DM. Gizi Prakonsepsi. Jakarta. Bumi Medika. 2019. Hal 52-53. 